overall there were fewer cases than expected (male, 19 cases $v 31 \cdot 2$ expected; female, 71 cases $v 85 \cdot 0$ expected). Within the parishes that formed the Copeland area around Sellafield nine cases were registered compared with $18 \cdot 4$ expected.

\section{Comment}

The decrease in radioactivity with distance from Sellafield is probably due to several factors, including the pattern of distribution of milk, which is generally assumed to be the principal source of ${ }^{129}$ I. Several points emerged from the study. Firstly, the specific activities varied widely even within the same residential area. This could be due to natural variation and differing diet as well as to the varying amounts of time people spend away from their homes. Secondly, the activities were low, most being under $10 \mathrm{mBq} / \mathrm{g}$ dry weight and none above $22 \mathrm{mBq} / \mathrm{g}$. This indicates that most of the sample population received less than an additional $0.67 \mu \mathrm{Sv} /$ year from this source, ${ }^{5}$ and none are likely to have received more than an additional 1.5 $\mu \mathrm{Sv} / \mathrm{year}$. This is small compared with the dose to the thyroid from normal background radiation, which in the Sellafield area is about $1000 \mu \mathrm{Sv} /$ year. Any cancers induced by this additional dose of ${ }^{129} \mathrm{I}$ are therefore unlikely to be detected above the natural incidence of the disease.

Even if higher levels of radioactivity occurred in the past these have not produced any detectable increase in the incidence of thyroid cancer. Two parishes with a significantly increased incidence were some distance from Sellafield; the increased incidence would therefore seem to be unrelated to any radioactive discharge from the nuclear fuel reprocessing works.

1 Stather JW' Wrixon AD, Simmonds JR. The risk of leukaemia and other cancers in Seascale from radiation exposure. London: HMSO, 1984. (National Radiological Protection Board report R171

2 Stather JW, Dionian J, Fell TP, Muirhead CR. The risks of leukaemia and other cancers in Seascale from radiation exposure. London: HMSO, 1986. (National Radiological Protection Board report R171 addendum.)

3 Greenhalgh JR, Fell TP, Adams N. Dose from intakes of radionuclides by adults and young people. London: HMSO, 1985. (National Radiological Protection Board report R162.

4 Baillar JC, Ederer F. Significance factors for the ratio of a Poisson variable to its expectation. Biometrics 1964; 20:639-43.

5 Snyder WS, Ford MR, Warner GC, Watson SB. Absorbed dose per unit cumulated activity for selected radionuclides and organs. $7 \mathrm{Nucl} \mathrm{Med}$ 1975; Medical Internal Radiation Dose Committee pamphlet 11.

(Accepted 24 April 1989)

\title{
Extension of selection criteria for extracorporeal shock wave lithotripsy for gall stones
}

\author{
A Darzi, J R T Monson, C O'Morain, \\ W A Tanner, F B V Keane
}

Departments of Clinical Surgery and Gastroenterology, Meath Hospital, Dublin 8

A Darzi, $\mathrm{MB}$, registrar in general surgery

J R T Monson, FRCS, registrar in general surgery

CO'Morain, FRCP, consultan physician

W A Tanner, FRCSI, consultant surgeon

F B V Keane, FRSC, consultant surgeon

Correspondence to: Mr Keane.

BrMed f 1989;299:302-3
Extracorporeal shock wave lithotripsy and dissolution treatment for gall stones have yielded encouraging results. ${ }^{12}$ Selection criteria, however, seem arbitrary and based on those already established for treatment with bile salts. ${ }^{3}$ As such criteria may restrict the number of patients treated we therefore extended the criteria and report our experience.

\section{Patients, methods, and results}

We treated 62 patients as outpatients between August 1987 and June 1988 (12 male, 50 female; mean age 46 (range 11-81)). Patients were selected if they had (a) symptomatic gall stone disease; $(b)$ radiolucent stones of any size or number or radio-opaque stones $\leqslant 3 \mathrm{~cm}$; and $(c)$ a functioning gall bladder on oral

Clearance of gall stones with shock wave lithotripsy in 49 patients based on stone profile

\begin{tabular}{|c|c|c|c|c|c|}
\hline \multirow[b]{2}{*}{ No of stones } & \multirow[b]{2}{*}{ Size of stones $(\mathrm{cm})$} & \multicolumn{4}{|c|}{ Clearance of stones } \\
\hline & & $100 \%$ & $\geqslant 50 \%$ & $<50 \%$ & 0 \\
\hline \multicolumn{6}{|c|}{ Radiolucent stones } \\
\hline 1 & $\left\{\begin{array}{l}<1 \\
2-3 \\
3-5\end{array}\right.$ & $\begin{array}{l}1 \\
6\end{array}$ & 1 & $1^{\star}$ & $\begin{array}{l}2 \\
1^{\star}\end{array}$ \\
\hline 2,3 & $\left\{\begin{array}{l}<1 \\
2-3\end{array}\right.$ & $\begin{array}{l}3 \\
1\end{array}$ & $\begin{array}{l}2 \\
2\end{array}$ & & \\
\hline$\geqslant 4$ & $\left\{\begin{array}{l}<1 \\
2-3\end{array}\right.$ & $\begin{array}{r}12^{\star} \\
1^{\star}\end{array}$ & $4^{\star} 1^{\star}$ & $1^{\star}$ & $\begin{array}{l}2^{\star} \\
1^{\star}\end{array}$ \\
\hline \multicolumn{6}{|c|}{ Radio-opaque stones } \\
\hline $\begin{array}{l}1 \\
2,3\end{array}$ & $\begin{array}{l}2-3 \\
2-3\end{array}$ & $1^{\star}$ & & & $2^{\star}$ \\
\hline$\geqslant 4$ & $\left\{\begin{array}{l}<1 \\
2-3\end{array}\right.$ & $\begin{array}{l}1^{\star} \\
1^{\star}\end{array}$ & & & $\begin{array}{l}1^{\star} \\
1^{\star}\end{array}$ \\
\hline Total & & 27 & 10 & 2 & 10 \\
\hline
\end{tabular}

$\star$ Patients who would not have been eligible for treatment with established selection criteria. cholecystography. Thirteen patients were excluded: four failed to return after the first treatment, two emigrated, one became pregnant, and two could not tolerate bile salt treatment; lithotripsy was abandoned in four because of difficulty in visualising the gall bladder.

All patients received combination dissolution treatment comprising chenodeoxycholic and ursodeoxycholic acid $7 \mathrm{mg} / \mathrm{kg} /$ day each, administered as one tablet (Lithofalk), and one capsule of a terpene mixture (Rowachol) three times daily. Ultrasonography was used to focus the shock waves from a piezoelectric lithotripter on the stones within the gall bladder. Each patient received 6000 shock waves in each treatment session (frequency 2.5 shock waves/s, $100 \%$ power) up to a maximum of six treatments at intervals of two to three weeks. All patients were followed up every month clinically and by ultrasonography. Two consecutive ultrasound scans and an oral cholecystogram were required to establish that the stones had been cleared

The 49 patients received 175 sessions of shock wave treatment, each patient requiring an average of three treatments (range one to six). The table shows the outcome related to number, size, and type of stones. We classified patients into four groups. One group comprised those in whom all stones were cleared $(n=27$; median follow up six months $(95 \%$ confidence interval 4.8 to $7 \cdot 5$ ) to time of clearance). The second group comprised those with $\geqslant 50 \%$ clearance - that is, fragmentation with appreciable clearance of stones ( $\mathrm{n}=10$; median follow up nine months). The third group comprised those with $<50 \%$ clearance - that is, fragmentation with little clearance of stones $(\mathrm{n}=2$; median follow up seven months). The fourth group comprised patients who had insignificant fragmentation or clearance of fragments after six treatment sessions and follow up of six months $(n=10)$.

Thirty one patients, including 16 of the 27 in whom all stones were cleared, would not have been deemed suitable for lithotripsy by previous criteria. ${ }^{12}$ Lithotripsy was generally well tolerated. Eight patients suffered biliary colic during follow up, which usually occurred within 48 hours after lithotripsy. One patient in whom treatment failed had transient jaundice four days after treatment, which resolved spontaneously. None had skin ecchymosis or haematuria or any clinical or biochemical evidence of acute pancreatitis. 


\section{Comment}

We estimate that up to $60 \%$ of the patients we treated after extending the selection criteria for treatment would otherwise have been treated by cholecystectomy. Treatment was most successful in patients with many small stones ( $\leqslant 1 \mathrm{~cm}$ diameter). The median time to clearance of stones in this group was seven months. This was shorter than would be expected with oral dissolution treatment alone, suggesting that lithotripsy played an important part. ${ }^{3+}$

The relative importance of extracorporeal fragmentation and oral dissolution treatment in this treatment is unclear. Sackman et al showed that bile salt treatment had a major influence on their results: stones were completely cleared in only $30 \%$ of their patients two months after lithotripsy compared with $93 \%$ at 18 months. ${ }^{1}$ We added a terpene compound to the bile salts, which may have enhanced dissolution and had an important antispasmodic effect, thus reducing biliary colic. ${ }^{5}$ Interestingly, only $16 \%$ of our patients had biliary colic compared with $35 \%$ reported by Sackman et al.'

We are grateful to $\mathrm{Mr}$ B Beesley and $\mathrm{Mr}$ J Coolican, who contributed data on several patients; Shona Beatty and Valerie Ingoldsby for their help in managing the patients; and Dr Falk $\mathrm{GmbH}$ and Rowa Pharmaceuticals for their support.

1 Sackman $M$, Delius $M$, Sauerbruch T, et al. Shock wave lithotripsy of gallstones. The first 175 patients. N Engl f Med 1988;318:393-7.

2 Ell C, Kerzel W, Heyder N, et al. Piezoelectric lithotripsy for gallbladder stones. Dtsch Med Wochenschr 1988;113:1503-7.

Roehrkasse R, Fromm H, Malavolti M, Tunuguntla AK, Ceryak S. Gallstone dissolution treatment with a combination of chenodeoxycholic and ursodeoxycholic acids. Studies of safety, efficacy and effects on bile lithogenicity, bile acid pool, and serum lipids. Dig Dis Sci 1986;31:1032-40.

4 Tint GS, Salen G, Colallilo A, et al. Ursodeoxycholic acid: a safe and effective agent for dissolving cholesterol gallstones. Ann Intern Med 1982:97:351-6.

Ellis WR, Somerville $\mathrm{KW}$, Whitren $\mathrm{BH}$, Bell GD. Pilot study of combination treatment for gallstones with medium dose terpene preparation. Br Med f 1984;289:153-6.

(Accepted 4 May 1989

\title{
Hypersensitivity vasculitis due to ofloxacin
}

\author{
David Huminer, Jonathan D Cohen, \\ Riad Majadla, Shlomo Dux
}

\section{Department of Internal Medicine C, Beilinson Medical Centre, Petah Tiqva 49100, Israel David Huminer, MD, lecturer Jonathan D Cohen, FCP, lecturer \\ Riad Majadla, MD, senior registrar}

Shlomo Dux, MD, lecturer

Correspondence and requests for reprints to: $\mathrm{Dr}$ Huminer.

BrMed f 1989;299:303
Since its introduction in 1985 the new fluoroquinolone antibiotic ofloxacin has gained widespread use and much information has accumulated about its possible adverse effects. ' Skin reactions have been uncommon ${ }^{12}$; in particular, no established case of hypersensitivity vasculitis directly related to ofloxacin has been reported.' We report such a case.

\section{Case report}

A 67 year old man was admitted to hospital because of a rash that had developed two days earlier. For the past 15 years he had had diabetes mellitus and congestive heart failure, for which he was taking isophane insulin 40 units in the morning and 12 units in the evening and frusemide $40 \mathrm{mg}$ daily. Two weeks before admission his right foot had been accidentally burnt and became infected. As povidone iodine baths were ineffective ofloxacin $200 \mathrm{mg}$ twice daily had been started three days before admission. One day later a pruritic purpuric rash had developed on his feet and legs. Ofloxacin was stopped and two days later the rash cleared. On the evening before admission he had taken another tablet of ofloxacin $200 \mathrm{mg}$, and a similar rash had developed.

On admission the rectal temperature was $36.9^{\circ} \mathrm{C}$. Physical examination showed an extensive papular purpuric rash on the feet and legs, swelling of the scrotum, pitting oedema of the legs, and an infected wound on the right foot. Blood cultures and cultures from the wound were sterile. The erythrocyte sedimentation rate (Westergren) was $42 \mathrm{~mm}$ in the first hour. A blood count yielded $11.4 \times 10^{9}$ leucocytes/l with $6 \%$ band forms and $2 \%$ eosinophils. Blood glucose concentration was $24.5 \mathrm{mmol} / \mathrm{l}$. Plasma urea concentration was $7.6 \mathrm{mmol} / \mathrm{l}$, creatinine $203 \mu \mathrm{mol} / \mathrm{l}$, alanine transaminase $114 \mathrm{U} / \mathrm{l}$, lactate dehydrogenase $407 \mathrm{U} / \mathrm{l}$, and alkaline phosphatase $288 \mathrm{U} / \mathrm{l}$. Blood tests for antinuclear antibody, rheumatoid factor, hepatitis B surface antigen, and cryoglobulins and the Venereal Disease Research Laboratory test yielded negative results. Serum C3 concentration was $0.56 \mathrm{~g} / 1$ (normal $0.70-1.76 \mathrm{~g} / \mathrm{l}$ ) and $\mathrm{C} 4$ concentration normal. Urine analysis showed a protein concentration of $3 \mathrm{~g} / \mathrm{l}$, a glucose concentration of $3 \mathrm{~g} / \mathrm{l}$, and 10 red cells per high power field. A mast cell degranulation test for ofloxacin gave a strongly positive result. A skin biopsy taken from the purpura shortly after admission showed leucocytoclastic angiitis.

Ofloxacin was stopped on admission and intravenous cefoxitin sodium and oral prednisone $40 \mathrm{mg}$ daily started. Insulin and frusemide were continued. The rash and the pedal and scrotal oedema resolved, and the liver and kidney functions improved. The dose of prednisone was rapidly reduced. On the 17 th day in hospital the patient was discharged.

\section{Comment}

This patient had clear evidence of a hypersensitivity vasculitis characterised clinically by a diffuse papular purpuric rash and histologically by a leucocytoclastic angiitis. Allergic vasculitis is a well known adverse effect of many drugs, including antibiotics and thiazide diuretics, ${ }^{3}$ and may occur with frusemide. ${ }^{+}$Our patient, however, had taken frusemide for many years without adverse effects and was still taking it when the rash resolved. Thus frusemide is unlikely to have caused the hypersensitivity vasculitis in this patient. Infection can cause allergic vasculitis, but this patient's vasculitis resolved despite a worsening infection. The temporal relation between the use of ofloxacin and the development of purpura and the resolution of the purpura after the drug was stopped and its reappearance after rechallenge suggest a causal relation. The strongly positive result of the mast cell degranulation test for ofloxacin confirms hypersensitivity to the drug.

Although four cases of allergic vasculitis during ofloxacin treatment have been reported in postmarketing surveillance studies, three cases seem to have been unrelated to the drug and not enough is known to evaluate the fourth.' Hypersensitivity vasculitis induced by ciprofloxacin, another fluoroquinolone antibiotic, has been reported. We suggest that hypersensitivity vasculitis be added to the growing list of adverse effects of the fluoroquinolones.

\footnotetext{
1 Jungst $\mathrm{G}$, Mohr R. Side effects of ofloxacin in clinical trials and in postmarketing surveillance. Drugs 1987;34 (suppl 1):144-9.

2 Paton JH, Reeves DS. Fluoroquinolone antibiotics. Microbiology, pharmacokinetics and clinical use. Drugs 1988;36:193-228.

3 Wintroub BU, Stern RS, Arndt KA. Cutaneous reactions to drugs. In: Fitzpatrick TB, Eisen AZ, Wolff $K$, Freedberg IM, Austen $K F$, eds. Dermatologv in general medicine. 3rd ed. New York: McGraw Hill, 1987: $1353-66$.

+ Lin RY. Unusual autoimmune manifestations in furosemide-associated with hypersensitivity angitis. NY State $\mathcal{F}$ Med 1988;88:439-40.

5 Cho U, Rothschield BM, Laitman L. Ciprofloxacin-induced vasculitis. $N$ Engl f. Med 1989;320:257-8

(Accepted 26 April 1989)
} 